\title{
A desensitization protocol to ganciclovir
}

\author{
Josefina Rodrigues Cernadas ${ }^{1 *}$, Fabrícia Carolino ${ }^{1}$, Ana Cláudia Carvalho², António Sarmento ${ }^{2}$ \\ From 6th Drug Hypersensitivity Meeting (DHM 6) \\ Bern, Switzerland. 9-12 April 2014
}

\section{Introduction}

The possibility to desensitize or induce a state of unresponsiveness to a drug that previously caused a hypersensitivity reaction is crucial when no equally safe or efficacious therapeutic alternative exists. The authors report the case of a successful desensitization to ganciclovir.

\section{Case report}

Hospitalized HIV-infected woman, 49 years-old, with AIDS, presenting with an active cytomegalovirus (CMV) gastrointestinal infection. On the second day of therapy with intravenous ganciclovir ( $250 \mathrm{mg}$, q12h), the patient developed an isolated pruriginous maculopapular exanthema localized to the torso and limbs. A hypersensitivity reaction to ganciclovir was suspected; by this time, all the other comorbidities were controlled and the decision to stop the drug was taken. Because the cutaneous lesions persisted for some time although on antihistaminic and corticosteroid, an alternative treatment to CMV - foscarnet - was initiated. Biopsy of the skin lesions was performed with a positive identification of CMV. Due frequent association of foscarnet to nephrotoxicity, reintroduction of ganciclovir was attempted on the sixth day of therapy, using a modified desensitization protocol based on a previously published protocol for rapid desensitization to chemotherapy. On the first day, a cumulative dose of $125 \mathrm{mg}$ was reached in 13 steps, without reactions. On the next day, adding two steps to the protocol, a dose of $250 \mathrm{mg}$ was safely administered. Dose increments between steps were relatively small, in an attempt to minimize the risk of reaction. The association of foscarnet and $250 \mathrm{mg}$ of ganciclovir was maintained for four days. The total daily therapeutic dose $(500 \mathrm{mg})$ of ganciclovir was reached under supervised slow perfusion (over 90 minutes) of $250 \mathrm{mg}$ every 12 hours. No clinical or analytical reactions were reported so foscarnet could be suspended, keeping intravenous ganciclovir as

${ }^{1} \mathrm{CH}$ São João, Immunoallergology Department, Portugal

Full list of author information is available at the end of the article monotherapy. After two weeks under full intravenous dose, the switch to oral treatment with valganciclovir was well tolerated.

\section{Comments}

To our knowledge, there are no published protocols of desensitization to ganciclovir. As viral infections might increase the risk of hypersensitivity reactions, treatment with foscarnet was maintained until the therapeutic dose of ganciclovir was reached, assuring full CMV treatment along all the process.

\section{Authors' details}

${ }^{1} \mathrm{CH}$ São João, Immunoallergology Department, Portugal. ${ }^{2} \mathrm{CH}$ São João, Infecciology Department, Portugal.

Published: 18 July 2014

doi:10.1186/2045-7022-4-S3-P60

Cite this article as: Cernadas et al:: A desensitization protocol to ganciclovir. Clinical and Translational Allergy 2014 4(Suppl 3):P60.

Submit your next manuscript to BioMed Central and take full advantage of:

- Convenient online submission

- Thorough peer review

- No space constraints or color figure charges

- Immediate publication on acceptance

- Inclusion in PubMed, CAS, Scopus and Google Scholar

- Research which is freely available for redistribution
C Biomed Central

c 2014 Cernadas et al; licensee BioMed Central Ltd. This is an Open Access article distributed under the terms of the Creative Commons Attribution License (http://creativecommons.org/licenses/by/4.0), which permits unrestricted use, distribution, and reproduction in any medium, provided the original work is properly cited. The Creative Commons Public Domain Dedication waiver (http://creativecommons.org/publicdomain/zero/1.0/) applies to the data made available in this article, unless otherwise stated. 